\title{
Volatility of mixed atmospheric humic-like substances and ammonium sulfate particles
}

\author{
Wei Nie ${ }^{1,2,3,8}$, Juan Hong ${ }^{3}$, Silja A. K. Häme ${ }^{3}$, Aijun Ding ${ }^{1,2,8}$, Yugen Li $^{4}$, Chao Yan ${ }^{3}$, Liqing Hao ${ }^{5}$, Jyri Mikkilä3 \\ Longfei Zheng ${ }^{1,2,8}$, Yuning Xie ${ }^{1,2,8}$, Caijun Zhu ${ }^{1,2,8}$, Zheng Xu ${ }^{1,2,8}$, Xuguang Chi ${ }^{1,2,8}$, Xin Huang ${ }^{1,2,8}$, Yang Zhou ${ }^{6,7}$, \\ Peng Lin ${ }^{6, a}$, Annele Virtanen ${ }^{5}$, Douglas R. Worsnop ${ }^{3}$, Markku Kulmala ${ }^{3}$, Mikael Ehn ${ }^{3}$, Jianzhen Yu ${ }^{6}$, \\ Veli-Matti Kerminen ${ }^{3}$, and Tuukka Petäjä ${ }^{3,1}$ \\ ${ }^{1}$ Joint International Research Laboratory of Atmospheric and Earth System Sciences, Nanjing University, Nanjing, China \\ ${ }^{2}$ Institute for Climate and Global Change Research \& School of Atmospheric Sciences, Nanjing University, \\ Nanjing, 210023, China \\ ${ }^{3}$ Division of Atmospheric Sciences, Department of Physics, University of Helsinki, Helsinki, Finland \\ ${ }^{4}$ Division of Environment, Hong Kong University of Science and Technology, Clear Water Bay, Kowloon, \\ Hong Kong SAR, China \\ ${ }^{5}$ Department of Applied Physics, University of Eastern Finland, Kuopio 70211, Finland \\ ${ }^{6}$ Department of Chemistry, Hong Kong University of Science \& Technology, Clear Water Bay, Kowloon, \\ Hong Kong SAR, China \\ ${ }^{7}$ Key Laboratory of Physical Oceanography, College of Oceanic and Atmospheric Sciences, Ocean University of China, \\ Qingdao 266100, China \\ ${ }^{8}$ Collaborative Innovation Center of Climate Change, Jiangsu province, China \\ ${ }^{a}$ now at: Environmental Molecular Sciences Laboratory, Pacific Northwest National Laboratory, Richland, WA 99532, USA
}

Correspondence to: Wei Nie (niewei@nju.edu.cn) and Aijun Ding (dingaj@nju.edu.cn)

Received: 20 September 2016 - Discussion started: 11 October 2016

Revised: 27 February 2017 - Accepted: 28 February 2017 - Published: 15 March 2017

\begin{abstract}
The volatility of organic aerosols remains poorly understood due to the complexity of speciation and multiphase processes. In this study, we extracted humic-like substances (HULIS) from four atmospheric aerosol samples collected at the SORPES station in Nanjing, eastern China, and investigated the volatility behavior of particles at different sizes using a Volatility Tandem Differential Mobility Analyzer (VTDMA). In spite of the large differences in particle mass concentrations, the extracted HULIS from the four samples all revealed very high-oxidation states $(\mathrm{O}: \mathrm{C}>0.95)$, indicating secondary formation as the major source of HULIS in Yangtze River Delta (YRD). An overall low volatility was identified for the extracted HULIS, with the volume fraction remaining (VFR) higher than $55 \%$ for all the regenerated HULIS particles at the temperature of $280^{\circ} \mathrm{C}$. A kinetic mass transfer model was applied to the thermodenuder (TD) data to interpret the observed evaporation pattern of HULIS, and to derive the mass fractions of
\end{abstract}

semi-volatile (SVOC), low-volatility (LVOC) and extremely low-volatility components (ELVOC). The results showed that LVOC and ELVOC dominated (more than $80 \%$ ) the total volume of HULIS. Atomizing processes led to a size-dependent evaporation of regenerated HULIS particles, and resulted in more ELVOC in smaller particles. In order to understand the role of interaction between inorganic salts and atmospheric organic mixtures in the volatility of an organic aerosol, the evaporation of mixed samples of ammonium sulfate (AS) and HULIS was measured. The results showed a significant but nonlinear influence of ammonium sulfate on the volatility of HULIS. The estimated fraction of ELVOC in the organic part of the largest particles $(145 \mathrm{~nm})$ increased from $26 \%$, in pure HULIS samples, to $93 \%$ in $1: 3$ (mass ratio of HULIS : AS) mixed samples, to $45 \%$ in $2: 2$ mixed samples, and to $70 \%$ in $3: 1$ mixed samples, suggesting that the interaction with ammonium sulfate tends to decrease the volatility of atmospheric organic compounds. Our results demonstrate 
that HULIS are important low-volatility, or even extremely low-volatility, compounds in the organic-aerosol phase. As important formation pathways of atmospheric HULIS, multiphase processes, including oxidation, oligomerization, polymerization and interaction with inorganic salts, are indicated to be important sources of low-volatility and extremely lowvolatility species of organic aerosols.

\section{Introduction}

Atmospheric organic aerosol (OA) comprises 20-90\% of the total submicron aerosol mass, depending on location (Kanakidou et al., 2005; Zhang et al., 2007; Jimenez et al., 2009), and plays a critical role in air quality and global climate change. Given the large variety of organic species, $\mathrm{OA}$ is typically grouped in different ways according to its sources and physicochemical properties. These include the classifications based on aerosol optical properties (brown carbon and non-light-absorbing OA), formation pathways (primary (POA) and secondary (SOA) organic aerosol), and solubility (water-soluble OA (WSOA) and water-insoluble OA (WISOA)). Humic-like substances (HULIS), according to their operational definition, are the hydrophobic part of WSOA, and contribute to more than half of the WSOA (e.g., Krivácsy et al., 2008). Secondary formation (Lin et al., 2010b) and primary emission from biomass burning (Lukács et al., 2007; Lin et al., 2010a) have been identified as the two major sources of atmospheric HULIS. Because they are abundantly present, water-soluble, light-absorbing and surface-active, HULIS in atmospheric particles have been demonstrated to play important roles in several processes, including cloud droplet formation, light absorption and heterogeneous redox activities (Kiss et al., 2005; Graber and Rudich, 2006; Hoffer et al., 2006; Lukács et al., 2007; Lin and Yu, 2011; Verma et al., 2012; Kristensen et al., 2012).

Volatility of atmospheric organic compounds is one of their key physical properties determining their partitioning between the gas and aerosol phases, thereby strongly influencing their lifetimes and concentrations. Atmospheric OA can be divided into semi-volatile organic compounds (SVOC), low-volatility organic compounds (LVOC) and extremely low-volatility organic compounds (ELVOC) (Donahue et al., 2012; Murphy et al., 2014). LVOC and ELVOC are predominantly in the aerosol phase and contribute largely to the new particle formation and growth (Ehn et al., 2014), while SVOC have considerable mass fractions in both phases and usually dominate the mass concentration of OA. As far as we know, volatility studies on OA have mostly focused on laboratory-generated organic particles or ambient particles (Kroll and Seinfeld, 2008; Bilde et al., 2015). Laboratorygenerated organic particles contain only a small fraction of compounds present in atmospheric OA, whereas ambient particles are usually complex mixtures of thousands of or- ganic and several inorganic compounds. One way to interlink laboratory and ambient studies, and to understand the volatility of ambient OA systematically, might be to isolate some classes of OA from ambient particles before investigating their volatility separately. As an important subgroup of organic aerosols in the real ambient aerosols, the physicochemical properties of HULIS have been studied widely, including their mass concentrations (Lin et al., 2010b), chemical composition (Lin et al., 2012; Kristensen et al., 2015; Chen et al., 2016), density (Dinar et al., 2006), and hygroscopicity (Wex et al., 2007; Kristensen et al., 2014). However, to the best of our knowledge, the volatility of atmospheric HULIS has never been reported so far.

In the ambient aerosol, organic aerosol (OA, including HULIS) mostly co-exist with inorganic compounds, such as ammonium sulfate. The volatility of OA has been demonstrated to be affected by aerosol-phase reactions when mixed with inorganic compounds (Bilde et al., 2015). The most typical examples of these are interactions between particulate inorganic salts with organic acids to form organic salts, which evidently can enhance the partitioning of organic acids onto the aerosol phase (Zardini et al., 2010; Laskin et al., 2012; Häkkinen et al., 2014; Yli-Juuti et al., 2013). Recent studies have reported that the saturation vapor pressure $\left(p_{\text {sat }}\right)$ of ammonium oxalate is significantly lower than that of pure oxalic acid, with $p_{\text {sat }}$ being around $10^{-6} \mathrm{~Pa}$ for ammonium oxalate (Ortiz-Montalvo et al., 2014; Paciga et al., 2014). However, this has not shown to be the case for adipic acid vs. ammonium adipate, indicating that not all dicarboxylic acids react with ammonium to form low-volatility organic salts (Paciga et al., 2014). Given that HULIS contain acidic species (Paglione et al., 2014; Chen et al., 2016), their interaction with inorganic salts would plausibly influence their volatility.

In this study, HULIS were extracted from $\mathrm{PM}_{2.5}$ filter samples collected at the SORPES station (Station for observing Regional Processes of the Earth System) in western Yangtze River Delta (YRD) during the winter of 2014 to 2015. A Volatility-Hygroscopicity Tandem Differential Mobility Analyzer (VH-TDMA) was then used to measure the volatility properties of extracted HULIS and their mixtures with ammonium sulfate. A kinetic mass transfer model was deployed to rebuild the measured thermograms, and to separate the mixture into three volatility fractions having an extremely low volatility, low volatility and semi-volatility. Our main goals were (1) to characterize the volatility of size-dependent, regenerated HULIS particles and to get insight into the relationship between atmospheric HULIS and ELVOC, and (2) to understand how the interaction between HULIS and inorganic salts affect their volatilities. 


\section{Methods}

\subsection{Sample collection and HULIS extraction}

The SORPES station is located on the top of a hill in the $\mathrm{Xi}$ anlin campus of Nanjing University, which is about $20 \mathrm{~km}$ east from the downtown Nanjing and can be regarded as a regional background site of Yangtze River Delta (YRD) (Ding et al., 2013, 2016). The samples collected here, especially during the polluted days, were believed to be regional representation of YRD. Samples of $24 \mathrm{~h} \mathrm{PM} 2.5$ were collected on quartz filters using a middle-volume $\mathrm{PM}_{2.5}$ sampler during the winter of 2014 to 2015 . HULIS were extracted from four aerosol samples for the following volatility measurements.

Water-soluble inorganic ions, organic carbon (OC) and elemental carbon (EC) were measured online using a Monitor for Aerosols and Gases in Air (MARGA) and a sunset OC/EC analyzer during the sampling periods. WSOC were extracted from portions of the sampled filters using sonication in ultrapure water with the ratio of $1 \mathrm{~mL}$ water per $1 \mathrm{~cm}^{2}$ filter. Insoluble materials were removed by filtering the extracts with a $0.45 \mu \mathrm{m}$ Teflon filter (Millipore, Billerica, MA, USA). A TOC analyzer with a nondispersive infrared (NDIR) detector (Shimadzu TOC-VCPH, Japan) was used to determine WSOC concentrations. The aerosol water extracts were then acidified to $\mathrm{pH}=2$ by $\mathrm{HCl}$ and loaded onto a SPE cartridge (Oasis HLB, $30 \mu \mathrm{m}, 60 \mathrm{mg} /$ cartridge, Waters, USA) to isolate the HULIS, following the procedure described in Lin et al. (2010b). Since the HULIS samples were in diluted water solutions rather than condensed-phase, and were acidified right before (in general, less than $15 \mathrm{~min}$ ) loading the sample on the SPE cartridge, we believe the acidcatalyzed reactions would unlikely take place to a significant degree as to influence their volatility (e.g., Birdsall et al., 2013). Most of the inorganic ions, low-molecular-weight organic acids and sugars were removed, with HULIS retaining on the SPE cartridge. A total of $20 \mathrm{~mL}$ of methanol was then used to elute the HULIS. The eluate was evaporated to dryness under a gentle stream of nitrogen gas. A part of the HULIS eluate was redissolved in $1.0 \mathrm{~mL}$ water to be quantified with an evaporative light scattering detector (ELSD). It should be noted here that HULIS extracted in this work refers to the part of water-soluble organic compounds that are partly hydrophobic in character. In case that the isolation processes may influence the evaporation behavior of HULIS by removing some species (especially the inorganic salts), which were originally mixed together with HULIS, we also reinduce ammonium sulfate, the most important inorganic salt, to the extracted HULIS and investigate the volatility of the mixed samples (Sect. 3.2).

\subsection{Volatility measurements by VTDMA measurements}

The evaporation behavior of water-soluble HULIS and their mixtures with AS was measured using a Volatility Tandem Mobility Analyzer, which is part of a VolatilityHygroscopicity Tandem Differential Mobility Analyzer (VH-TDMA) system (Hong et al., 2014). During the measurements, the hygroscopicity mode was deactivated, so that only the volatility mode of this instrument was functioning. Briefly, aerosol particles were generated by atomizing aqueous solutions consisting of HULIS and their mixtures with AS by using an atomizer (TOPAS, ATM 220). Then, a monodisperse aerosol with particle sizes of $30,60,100$, and $145 \mathrm{~nm}$ were selected by a Hauke-type Differential Mobility Analyzer (DMA, Winklmayr et al., 1991). The monodisperse aerosol flow was then heated by a thermodenuder at a certain temperature, after which the number size distribution of the particles remaining was determined by a second DMA and a condensation particle counter (CPC, TSI 3010). The thermodenuder was a $50 \mathrm{~cm}$ long stainless steel tube with an average residence time of around $5 \mathrm{~s}$.

The VTDMA measures the shrinkage of the particle diameter after heating particles of some selected initial size at different temperatures. Conventionally, the volume fraction remaining (VFR), i.e., the fraction of aerosol mass left after heating particles of diameter $D_{\mathrm{p}}$, is used to describe the evaporation quantitatively. $D_{\mathrm{p}}\left(T_{\text {room }}\right)$ is the initial particle diameter at room temperature. $D_{\mathrm{p}}(T)$ is the particle diameter after passing through the thermodenuder at the temperature $T$.

The VFR can be defined as the following:

$\operatorname{VFR}\left(D_{\mathrm{p}}\right)=\frac{D_{\mathrm{p}}^{3}(T)}{D_{\mathrm{p}}^{3}\left(T_{\text {room }}\right)}$,

In this work, we analyzed a total of eight samples, with six of them collected during winter and the other two during summer, and covering a wide range of PM concentration from less than $40 \mu \mathrm{g} \mathrm{m}^{-3}$ to higher than $150 \mu \mathrm{g} \mathrm{m}^{-3}$. All these eight samples showed similar evaporation behavior with some small differences in details (Fig. S1 in the Supplement). Therefore, in terms of volatility, we believe that there were no large differences among individual samples of the water-soluble HULIS fraction. Hence, we selected only four of the samples to represent the range of HULIS samples collected at the SORPES station.

\subsection{Kinetic mass transfer model}

A kinetic mass transfer model (Riipinen et al., 2010) was applied to help interpreting the HULIS evaporation data. The size distribution, chemical composition and physicochemical properties of the regenerated HULIS particles, as well as the residence time of the particles traveling through the thermodenuder, were predefined in the model. As an output, 
the model provided the particle mass change as a function of the residence time, which can either increase or decrease, depending on the particle composition, the volatility of compounds and concentrations of surrounding vapors. With the aim to reproduce the observed evaporation pattern of HULIS particles measured by the VTDMA, the model applied an optimization procedure to minimize the difference between the measured and modeled evaporation curves of the HULIS particles.

In the model, particles were assumed to consist of compounds that can be grouped into three volatility bins: semivolatile, low-volatility and extremely low-volatility components. These three "bins" were quantified by assuming that they had fixed volatilities with $p_{\text {sat }}(298 \mathrm{~K})=\left[10^{-3}\right.$ $10^{-6} 10^{-9} \mathrm{~Pa}$. Modeling was performed for each experiment/sample separately, with four samples and four different initial particle sizes $\left(D_{\mathrm{p}}=30,60,100\right.$ and $\left.145 \mathrm{~nm}\right)$, leading to 16 different model runs, each providing information on how much semi-volatile, low-volatility and extremely low-volatility matter $\left(X_{i}\right)$ was present in the investigated particles. The initial particle size refers to the particle diameter prior to heating. The values for $p_{\text {sat }}(298 \mathrm{~K})$ and $\Delta H_{\text {vap }}$ (see Table 1 and the text above) were selected by doing a preliminary test model runs. With $\Delta H_{\mathrm{vap}}$ of around [40 4040$] \mathrm{kJ} \mathrm{mol}^{-1}$ and $p_{\text {sat }}(298 \mathrm{~K})$ of $\left[10^{-3} 10^{-6} 10^{-9}\right] \mathrm{Pa}$ the model was best able to reproduce the observed evaporation curves of the HULIS aerosol. Such low vaporization enthalpies (referred often as effective vaporization enthalpies) for aerosol mixtures, for example for SOA from $\alpha$-pinene oxidation, have been reported also in previous studies (Häkkinen et al., 2014; Donahue et al., 2005; Offenberg et al., 2006; Riipinen et al., 2010). The molecular weight and density of HULIS were assumed to be $280 \mathrm{~g} \mathrm{~mol}^{-1}$ (Kiss et al., 2003; Lin et al., 2012) and $1.55 \mathrm{~kg} \mathrm{~m}^{-3}$ (Dinar et al., 2006), respectively. Since the value of mass accommodation coefficient (MAC) may influence the simulated volatility distribution of HULIS, sensitivity of this kinetic evaporation model was tested towards different values of mass accommodation coefficient (i.e., $\mathrm{MAC}=1,0.1,0.01$ ) for both pure HULIS sample and mixed samples (figure not shown). The results suggested that 1 is the proper MAC value to best reproduce the measured evaporation behavior (Table 1).

Volatility information, specifically described as the saturation vapor pressure and vaporization enthalpy here, of ammonium sulfate was determined by interpreting the evaporation behavior of laboratory-generated AS particles using the kinetic evaporation model. By setting the saturation vapor pressures and enthalpy of vaporization of AS as fitting parameters, the optimum solution was obtained by minimizing the difference between the measured and modelinterpreted thermograms of AS particles. Hence, $p_{\text {sat }}(298 \mathrm{~K})$ of $1.9 \times 10^{-8} \mathrm{~Pa}$ and $\Delta H_{\mathrm{vap}}$ of $97 \mathrm{~kJ} \mathrm{~mol}^{-1}$ for AS were determined and used in the following analysis.

\subsection{AMS measurement for oxygen to carbon ratio}

The O : C (oxygen to carbon) ratios of regenerated HULIS particles were measured using a high-resolution time-offlight aerosol mass spectrometer (HR-Tof-AMS, Aerodyne Research Inc., Billerica, USA). Detailed descriptions of the instrument and data processing can be found in previous publications (DeCarlo et al., 2006; Canagaratna et al., 2007). The HULIS solution was atomized to generate polydispersed aerosol particles and introduced into AMS. The AMS was operated in $V$ mode and the data were acquired at 5 min saving intervals. The AMS data were analyzed using standard Tof-AMS data analysis toolkits (SQUIRREL version $1.57 \mathrm{H}$ and PIKA version $1.16 \mathrm{H}$ ) in Igor Pro software (version $6.22 \mathrm{~A}$, WaveMetrics Inc). For mass calculations, the default relative ionization efficiency (RIE) values 1.1, 1.2, 1.3 and 1.4 for nitrate, sulfate, chloride and organic were applied, respectively. The RIE for ammonium was 2.6, determined from the ionization efficiency calibration. In elemental analysis, the "Improved- Ambient" method was applied to calculate $\mathrm{O}: \mathrm{C}$ ratios by considering the $\mathrm{CHO}^{+}$ion correction (Canagaratna et al., 2015).

\section{Results and discussions}

Figure 1 shows the chemical compositions of the four $\mathrm{PM}_{2.5}$ samples, and the oxygen to carbon ratio $(\mathrm{O}: \mathrm{C})$ of the extracted HULIS in related samples. The four samples can be classified into two groups based on their $\mathrm{PM}_{2.5}$ concentrations (the sum of all measured chemical compositions), with one group (samples 1 and 2) having the $\mathrm{PM}_{2.5}$ higher than $110 \mu \mathrm{g} \mathrm{m}^{-3}$ and the other one (samples 3 and 4) having the $\mathrm{PM}_{2.5}$ lower than $40 \mu \mathrm{g} \mathrm{m}^{-3}$. The concentrations of inorganic compounds (sulfate, nitrate and ammonium) were significantly higher in samples 1 and 2 than in samples 3 and 4 . The HULIS concentrations were also higher in samples 1 and 2 (about $9 \mu \mathrm{g} \mathrm{m}^{-3}$; the ratio of HULIS-carbon to OC was about 0.3 ) than in samples 3 and 4 (about $6 \mu \mathrm{g} \mathrm{m}^{-3}$, ratio of HULIS-carbon to OC were about 0.4 ). The oxidation states of the HULIS, however, did not show any notable differences, showing very high values for all the four samples $(\mathrm{O}: \mathrm{C}>0.95)$, indicating that the HULIS in YRD could be mostly secondarily formed even during the relatively clean days. Such high-oxidation states suggest that the extracted HULIS were very likely highly-oxidized, multifunctional compounds (HOMs) originating from multiphase oxidation (Graber and Rudich, 2006). One possible source of these HOMs is the oxidation of aromatics, which initiated by hydroxyl radical $(\mathrm{OH})$ and followed by auto-oxidation (Molteni et al., 2016).

\subsection{Volatility of atmospheric water-soluble HULIS}

The volume fraction remaining (VFR) of the HULIS particles as a function of the heating temperature obtained from 
Table 1. Kinetic model input settings for three-component HULIS aerosol.

\begin{tabular}{|c|c|c|}
\hline Model input parameter & Unit & HULIS \\
\hline Molar mass, $M$ & $\mathrm{~g} \mathrm{~mol}^{-1}$ & {$\left[\begin{array}{llllllll}280 & 280 & 280\end{array}\right]$} \\
\hline Density, $\rho$ & $\mathrm{kg} \mathrm{m}^{-3}$ & {$\left[\begin{array}{llll}1550 & 1550 & 1550\end{array}\right]$} \\
\hline Surface tension, $\sigma$ & $\mathrm{Nm}^{-1}$ & {$\left[\begin{array}{llll}0.05 & 0.05 & 0.05\end{array}\right]$} \\
\hline Diffusion coefficient, $D$ & $10^{-6} \mathrm{~m}^{2} \mathrm{~s}^{-1}$ & {$\left[\begin{array}{lll}5 & 5 & 5\end{array}\right]$} \\
\hline Parameter for the calculation of $T$-dependence of $D, \mu$ & - & {$\left[\begin{array}{llll}1.75 & 1.75 & 1.75\end{array}\right]$} \\
\hline Saturation vapor pressure, $p_{\text {sat }}(298 \mathrm{~K})$ & $\mathrm{Pa}$ & {$\left[10^{-3} 10^{-6} 10^{-9}\right]$} \\
\hline Saturation vapor concentration, $c_{\text {sat }}(298 \mathrm{~K})$ & $\mu \mathrm{g} \mathrm{m}^{-3}$ & {$\left[10^{2} 10^{-1} 10^{-4}\right]$} \\
\hline Enthalpy of vaporization, $\Delta H_{\mathrm{vap}}$ & $\mathrm{kJ} \mathrm{mol}^{-1}$ & {$\left[\begin{array}{lll}40 & 40 & 40\end{array}\right]$} \\
\hline Mass accommodation coefficient, $\alpha_{\mathrm{m}}$ & - & {$\left[\begin{array}{lll}1 & 1 & 1\end{array}\right]$} \\
\hline Activity coefficient, $\gamma$ & - & {$\left[\begin{array}{lll}1 & 1 & 1\end{array}\right]$} \\
\hline Particle initial diameter, $d_{\mathrm{p}}$ & $\mathrm{nm}$ & $30,60,100,145$ \\
\hline \multirow[t]{2}{*}{ Particle total mass, $m_{\mathrm{p}, \text { tot }}$} & $\mu \mathrm{g} \mathrm{m}^{-3}$ & 1 \\
\hline & & Thermodenuder \\
\hline Length of the flow tube & $\mathrm{m}$ & 0.50 (i.d. of $6 \mathrm{~mm}$ ) \\
\hline Residence time & $\mathrm{s}$ & 5 \\
\hline
\end{tabular}

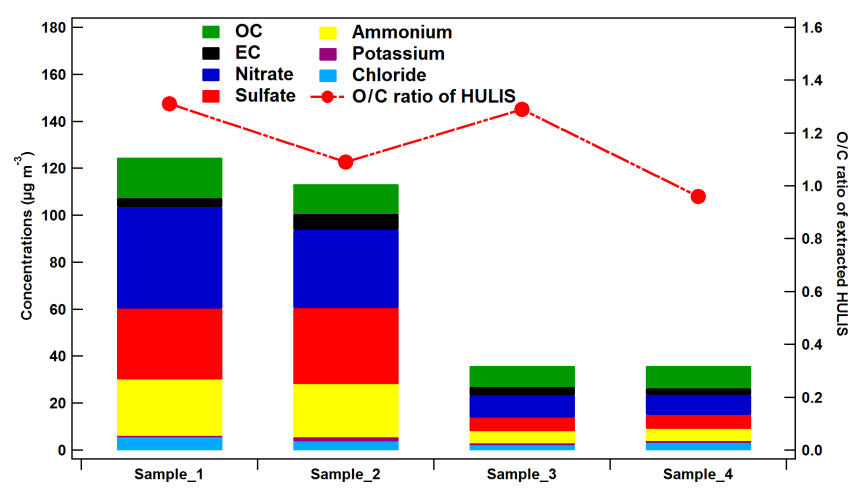

Figure 1. Chemical composition of the four $\mathrm{PM}_{2.5}$ samples collected at SORPES station and oxygen to carbon ratio of extracted HULIS from related samples.

VTDMA is illustrated in Fig. 2. An overall low volatility was identified for the HULIS particles, with the VFR higher than $55 \%$ for the particles of all four sizes at the heating temperature of $280^{\circ} \mathrm{C}$ and residence time of $5 \mathrm{~s}$. Small differences in the volatility could be observed between the samples of high-mass concentrations and low-mass concentrations in that the evaporation of HULIS in samples 1 and 2 was in general weaker than that in samples 3 and 4 . In addition, all the samples started to evaporate from the very beginning of the heating program (around 20 to $25^{\circ} \mathrm{C}$ ) and the evaporation curves varied smoothly, suggesting that the HULIS particles were mixtures of compounds having wide range of saturation vapor pressures.

A kinetic mass transfer model was applied to reproduce the observed evaporation of the HULIS, and to estimate the mass fractions of semi-volatile (SVOC, $\left.p_{\text {sat }}(298 \mathrm{~K})=10^{-3} \mathrm{~Pa}\right), \quad$ low-volatility $\left(\mathrm{LVOC}, \quad p_{\text {sat }}\right.$ $\left.(298 \mathrm{~K})=10^{-6} \mathrm{~Pa}\right)$ and extremely low-volatility organic components $\left(\right.$ ELVOC, $\left.p_{\text {sat }}(298 \mathrm{~K})=10^{-9} \mathrm{~Pa}\right)$. As shown in Fig. 3, the model performed reasonably well in simulating the "pure" HULIS particles (example for sample 1). Noting that the HULIS mixtures were represented with only three model compounds of different volatilities, the modeled evaporation curves of the HULIS in all samples showed a relatively good agreement with the measured evaporation curves for all the four particle sizes. The shape of the modeled thermograms is not as smooth as that of the measured ones suggesting lower number of volatilities in simulations compared to the real samples. The model-simulated distributions of SVOC, LVOC and ELVOC of each water-soluble HULIS sample gave indication on the volatility of HULIS. As shown in Fig. 4, all the water-soluble HULIS consisted of compounds from all the three volatility "bins", further confirming HULIS to be mixtures of compounds with wide range of volatilities. SVOC was estimated to account for only a small proportion (less than $20 \%$ of the particle mass) of the water-soluble HULIS, while LVOC and ELVOC dominated these samples (78-97\% of the particle mass), suggesting an overall low volatility of the extracted water-soluble HULIS. Given that the heating program has the potential to raise the evaporation of HULIS by decomposing large molecules, the real volatility of atmospheric HULIS could be even lower than obtained here. Detailed molecular information of extracted HULIS was not available in this study. But a previous study at the Pearl River Delta, another polluted megacity region in China, showed the molecular weight of HULIS was in the range of 100 to 500, with a significant fraction higher than 260 . Using the method provided by $\mathrm{Li}$ et al. (2016) to estimate the volatility of these compounds, we calculated that a large fraction of these compounds in water-soluble HULIS was LVOC or ELVOC, especially the 

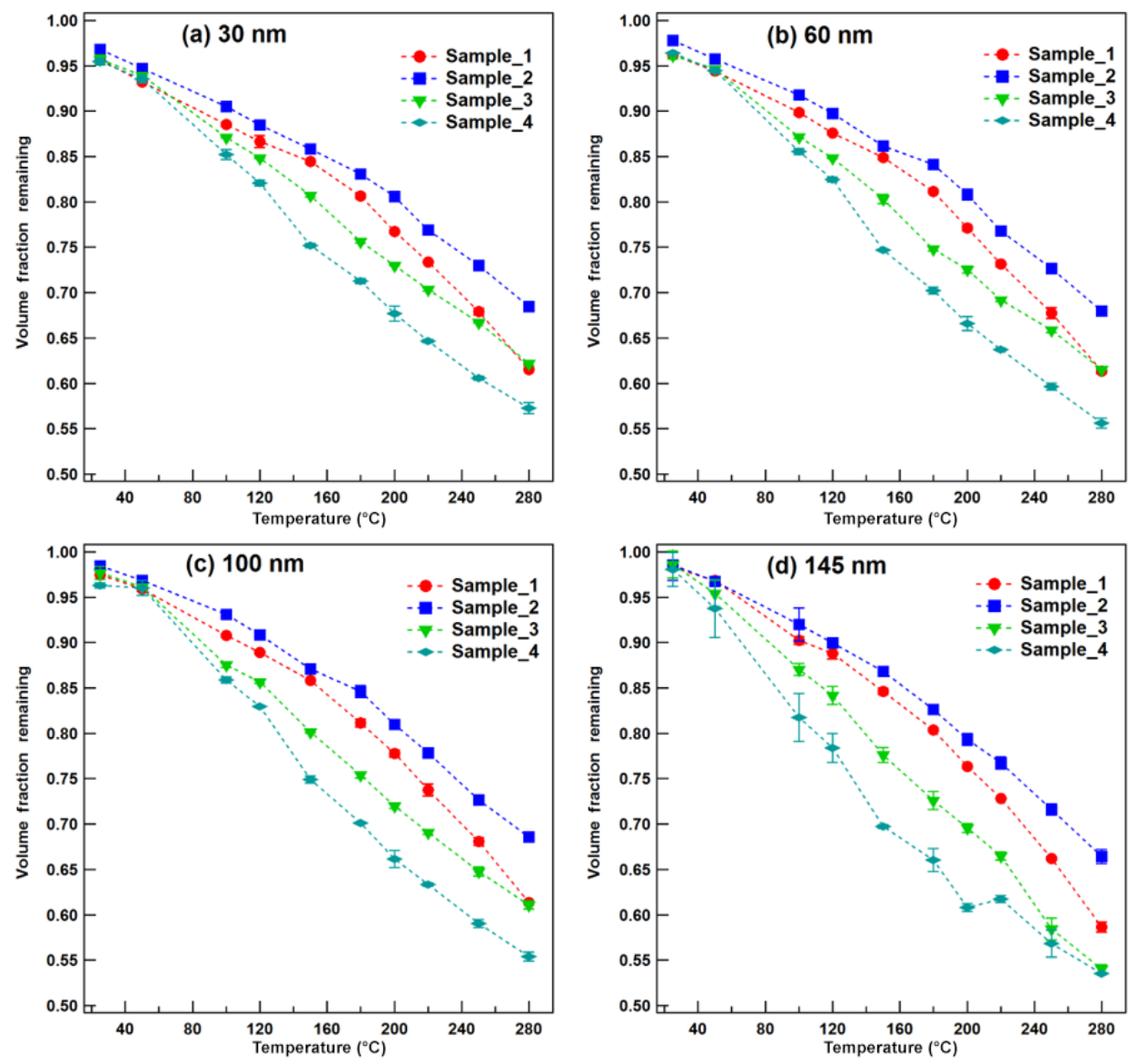

Figure 2. Volume fraction remaining (VFR) as a function of heating temperature for four samples at four different sizes of (a) $30 \mathrm{~nm}$, (b) $60 \mathrm{~nm}$, (c) $100 \mathrm{~nm}$, and (d) $145 \mathrm{~nm}$.

S-containing compounds with molecular weight higher than 200. Future volatility measurement studies are suggested to investigate the S-containing compounds.

In spite of their overall low values, the volatilities of the water-soluble HULIS varied between the different samples. The HULIS extracted from the samples of higher particle mass loadings (samples 1 and 2) had, in general, lower volatilities than those extracted from the samples of lower particle mass concentrations (samples 3 and 4). By taking $30 \mathrm{~nm}$ particles as an example, sample 2 had the largest mass fraction of ELVOC, up to $72 \%$, followed by sample 1 (66\%) and sample $3(64 \%)$, while sample 4 had the least amount of ELVOC (58\%). Correspondingly, the mass fraction of SVOC in $30 \mathrm{~nm}$ particles was the highest in sample $4(9 \%)$ and the lowest in sample $2(6 \%)$. Several factors, including the molecular weight, oxidation state and molecular structure of the compounds, as well as their interaction with other compounds, can influence the volatility of HULIS. Although there is not enough information to support the final conclusion, we excluded the oxidation state as a key factor here because its variation did not match the volatility changes of the HULIS samples. As can be seen from Figs. 1 and 4, sam- ple 2 showed the lowest volatility but the third highest oxidation state of the four samples. Instead of the oxidation state, the interaction between water-soluble HULIS and inorganic species is a more likely candidate for influencing the observed variation of the HULIS volatility, especially as the lower-volatility samples (samples 1 and 2) had higher concentrations and fractions of inorganic species (Fig. 1).

Within individual HULIS samples, the estimated amount of ELVOC, LVOC and SVOC varied with the particle size (Fig. 4). The mass fraction of ELVOC was in the range of $58-72 \%$ for the smallest particles $(30 \mathrm{~nm}$ in diameter) and decreased to the range of $47-60 \%$ for the $60 \mathrm{~nm}$, to the range of $35-53 \%$ for the $100 \mathrm{~nm}$ particles, and to the range of $20-39 \%$ for the $145 \mathrm{~nm}$ particles. The amount of LVOC increased correspondingly with an increasing particle size, from $23-33 \%$ for the $30 \mathrm{~nm}$ particles to $52-65 \%$ for the $145 \mathrm{~nm}$ particles. The amount of SVOC slightly increased with an increasing particle size, on average from $7.5 \%(30 \mathrm{~nm})$ to $14.5 \%(145 \mathrm{~nm})$. The most likely explanation for this behavior is that, due to the Kelvin effect, compounds with higher volatilities are likely to evaporate more from smaller particles. This result indicates that size- 

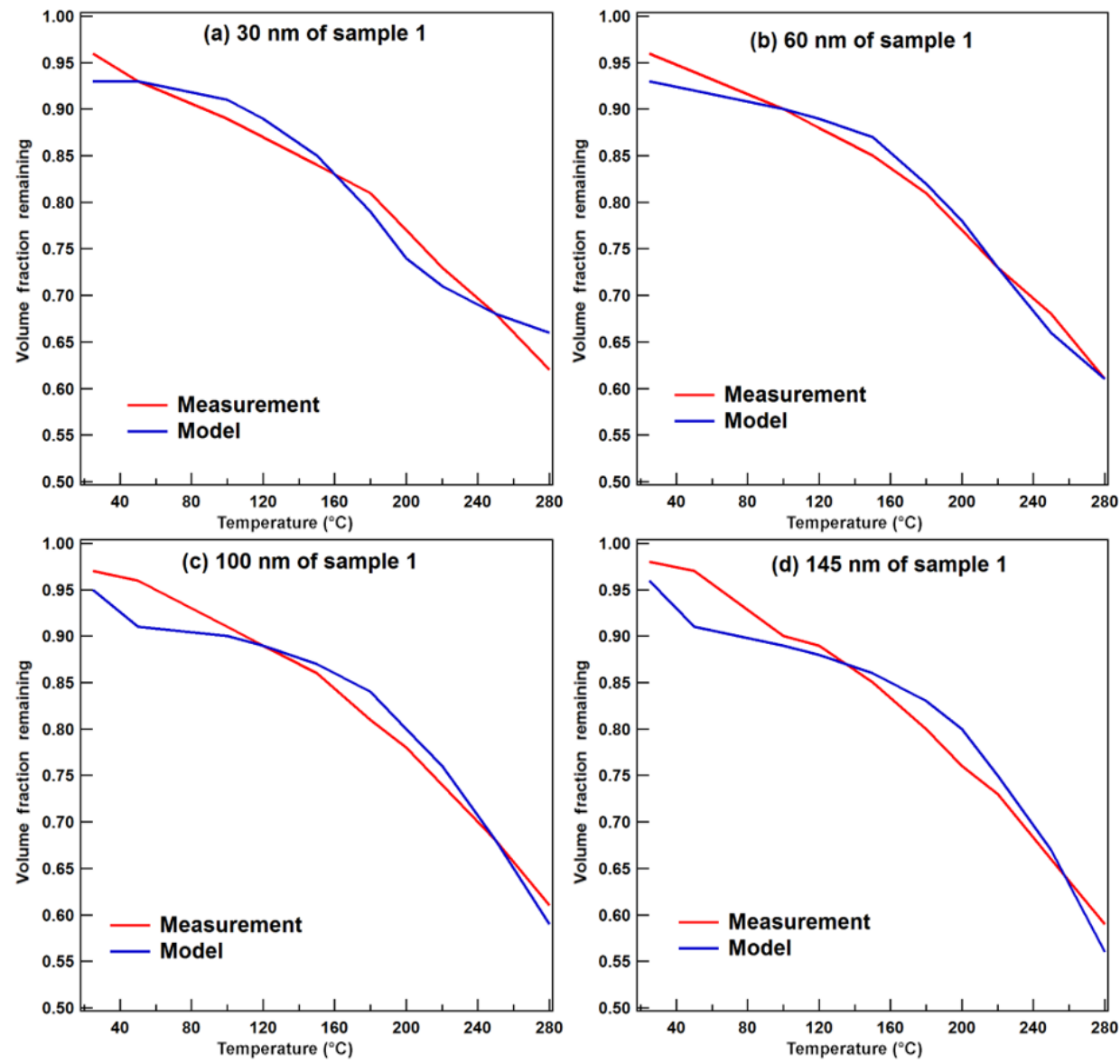

Figure 3. Measured and modeled volume fraction remaining (VFR) as a function of temperature for HULIS of sample 1 at four different particle sizes of (a) $30 \mathrm{~nm}$, (b) $60 \mathrm{~nm}$, (c) $100 \mathrm{~nm}$, and (d) $145 \mathrm{~nm}$.

resolved chemical compositions of laboratory-generated particles from aqueous solutions of mixtures should be examined more carefully to support their size-dependent physical properties from lab studies.

\subsection{Interaction between water-soluble HULIS and ammonium sulfate}

Organic material, including HULIS, is always mixed with inorganic species in the real ambient aerosol. Their interactions have been shown to influence the volatility of the organic matter. However, recent work has focused on the interaction between one specific organic compound and some inorganic salt(s). For example, Laskin et al. (2012) observed the formation of sodium organic salt in a submicron organic acid- $\mathrm{NaCl}$ aerosol. Ma et al. (2013) reported that the formation of sodium oxalate can occur in particles containing oxalic acid and sodium chloride. Häkkinen et al. (2014) demonstrated that low-volatility material, such as organic salts, were formed within aerosol mixtures of inorganic compounds with organic acids. Zardini et al. (2010) and Yli-Juuti et al. (2013) suggested that interactions between inorganic salts and organic acids in the particle phase might further enhance the partitioning of organic acids onto the particle phase. Given the complex nature of organic aerosols in the real atmosphere, large uncertainties will be induced when using simplified laboratory results for explaining observations in the real atmosphere. In this study, we investigated the volatility of mixed samples of HULIS and ammonium sulfate in different ratios in order to get a better understanding of organic-inorganic interactions under atmospherically relevant conditions.

Three samples were prepared by mixing water-soluble HULIS (extracted from sample 1) and pure ammonium sulfate (AS) with the mass ratios (HULIS to AS) of $0.25: 0.75$, $0.5: 0.5$ and $0.75: 0.25$ (actually $0.29: 0.71,0.55: 0.45$ and $0.79: 0.21$ ). As shown by Fig. 5 , pure ammonium sulfate particles started to evaporate at $100^{\circ} \mathrm{C}$, and were almost entirely evaporated at $180^{\circ} \mathrm{C}$, whereas HULIS aerosol started to evaporate at the very beginning (about $20^{\circ} \mathrm{C}$ ) and more than $80 \%$ of its volume still remained at $180^{\circ} \mathrm{C}$. The evaporation curves for the three mixed samples (Fig. 6) showed generally slow evaporation rates within the temperature windows from 20 to $100^{\circ} \mathrm{C}$ and from 180 to $280^{\circ} \mathrm{C}$, and much 

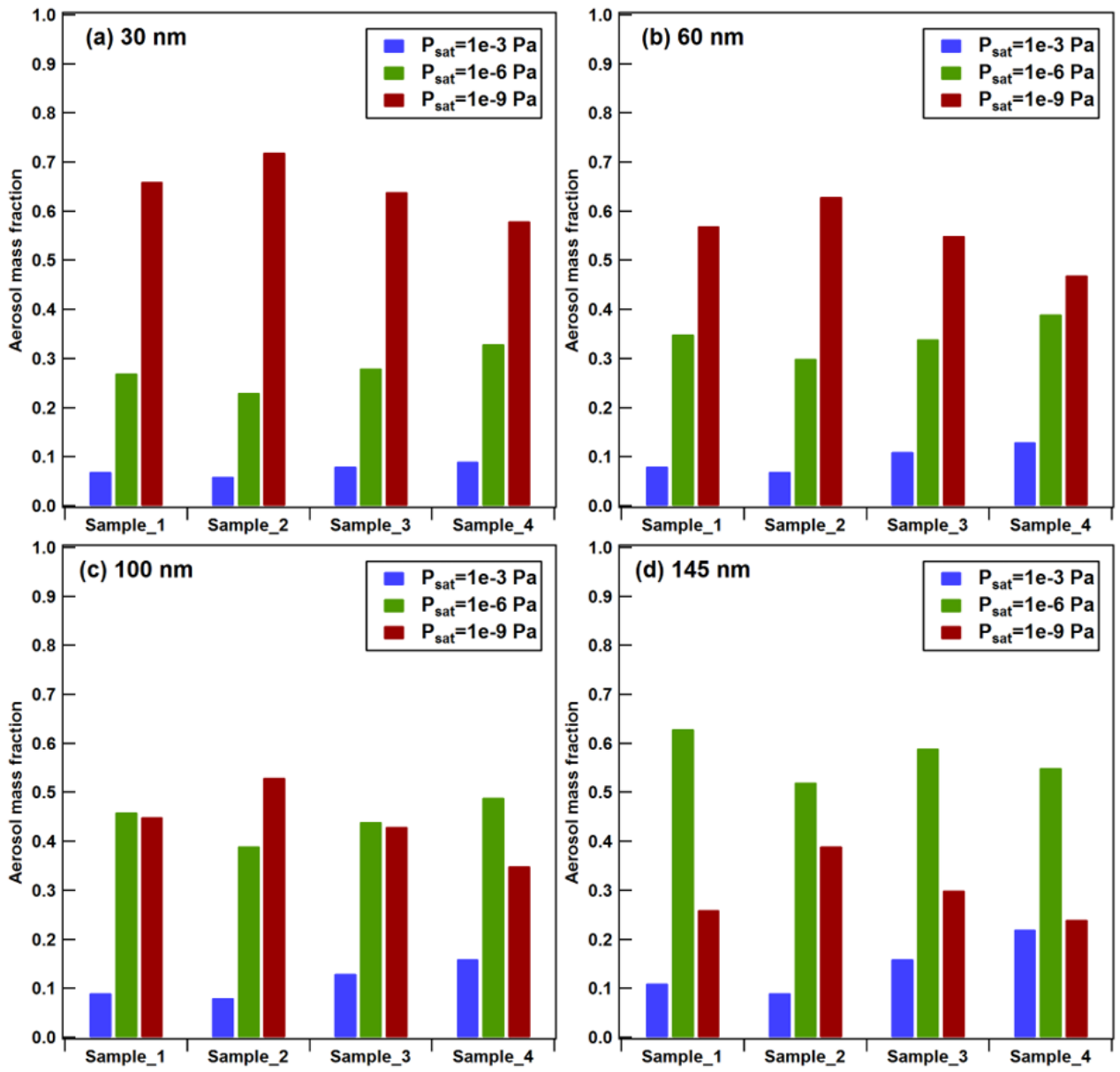

Figure 4. Mass fractions of compounds of SVOC ( $\left.p_{\text {sat }}=10^{-3} \mathrm{~Pa}\right), \operatorname{LVOC}\left(p_{\text {sat }}=10^{-6} \mathrm{~Pa}\right)$ and ELVOC $\left(p_{\text {sat }}=10^{-9} \mathrm{~Pa}\right)$ in four aerosol samples with different particle sizes of (a) $30 \mathrm{~nm}$, (b) $60 \mathrm{~nm}$, (c) $100 \mathrm{~nm}$, and (d) $145 \mathrm{~nm}$.
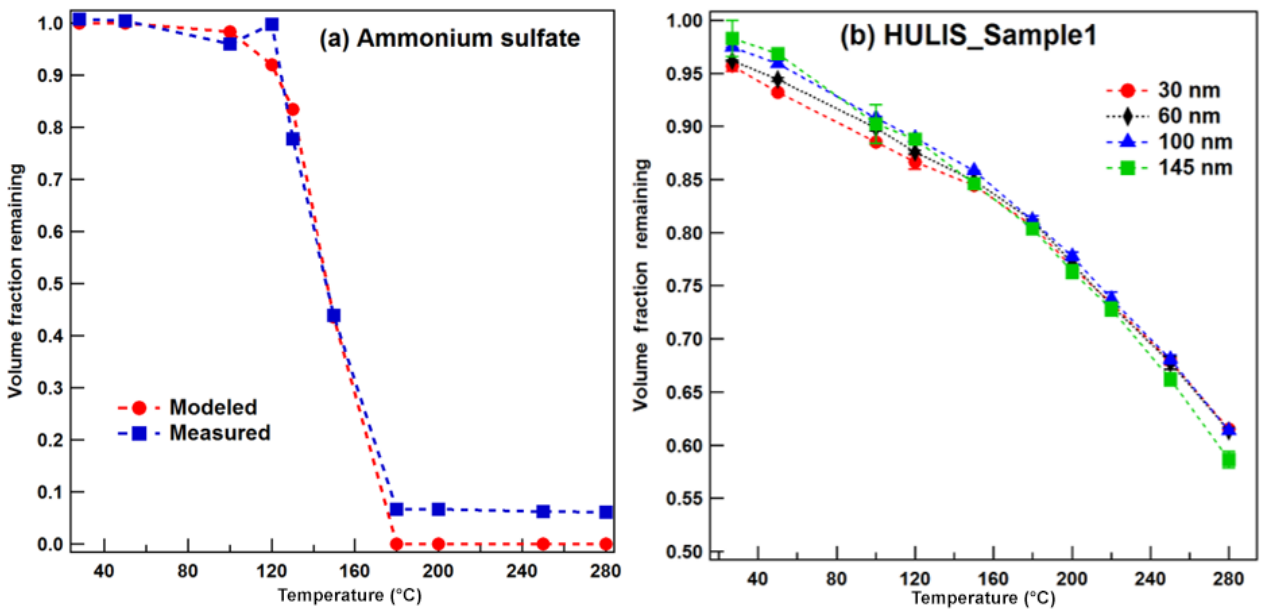

Figure 5. Volume fraction remaining (VFR) as a function of heating temperature for (a) measured and modeled pure ammonium sulfate particles at $100 \mathrm{~nm}$, and (b) HULIS sample 1 at four different sizes of 30, 60, 100, and $145 \mathrm{~nm}$. 

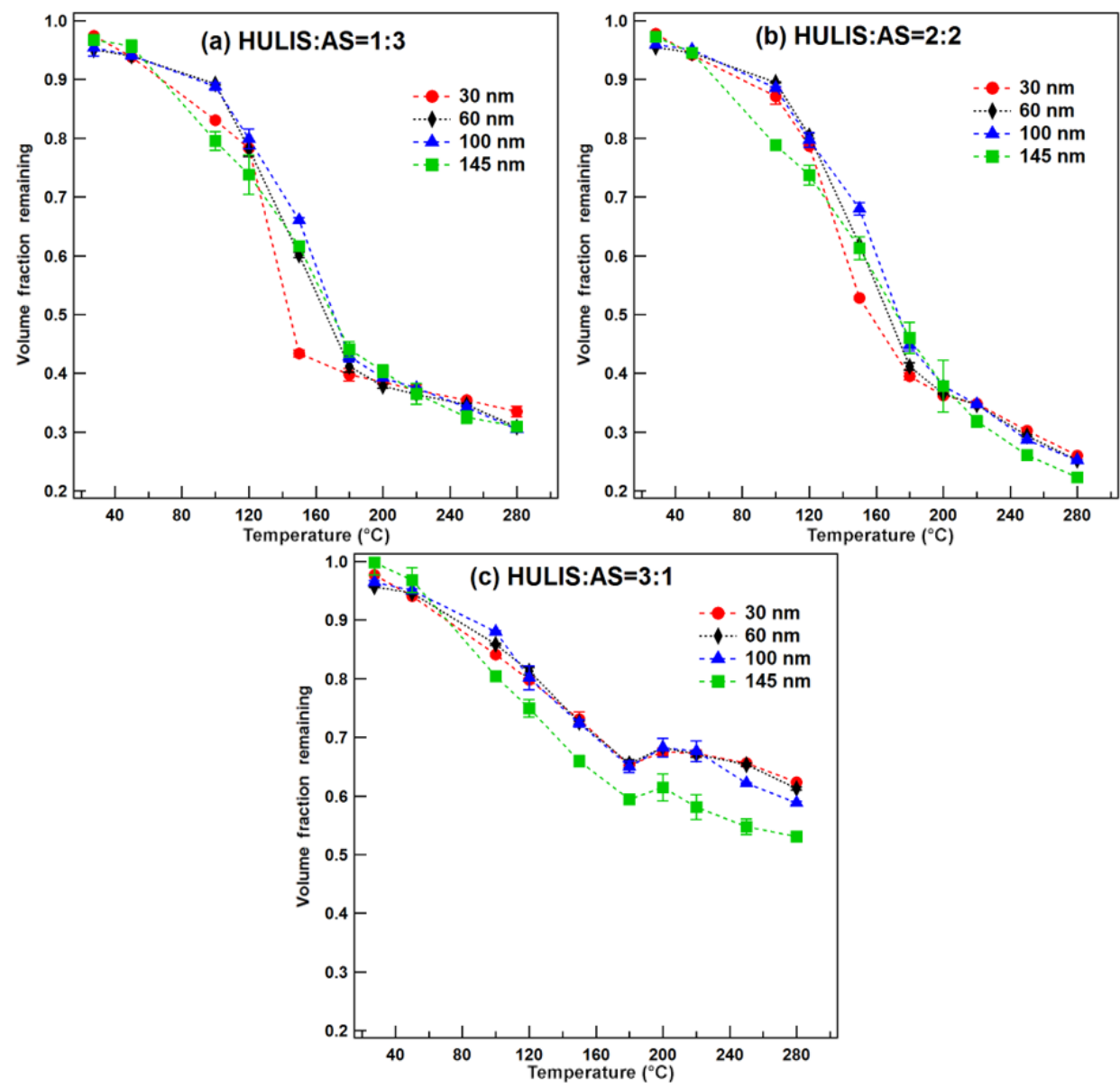

Figure 6. Volume fraction remaining (VFR) as a function of heating temperature for (a) $1: 3$ HULIS-AS mixed sample, (b) $2: 2$ HULIS-AS mixed samples, and (c) 3:1 HULIS-AS mixed samples at four different sizes of 30,60, 100, and $145 \mathrm{~nm}$.

faster evaporation rates between 100 and $180^{\circ} \mathrm{C}$. Interactions between water-soluble HULIS and ammonium sulfate obviously influenced the observed volatility. For example, the VFRs of $0.25: 0.75$ samples (Fig. 6a) at the temperature of $180^{\circ} \mathrm{C}$ were around 0.4 (varied from 0.397 to 0.428 for different size particles), which is significantly higher than the calculated VFR $(0.29 \times 0.8+0.71 \times 0.06=0.275)$, by assuming water-soluble HULIS and ammonium sulfate independently separated. This indicates that mixing of ammonium sulfate to a solution of water-soluble HULIS decreases the volatility of the organic group or, alternatively, forms new compounds of low volatility. For the $0.5: 0.5$ and $0.75: 0.25$ samples (Fig. $6 \mathrm{~b}$ and c), the VFRs at $180^{\circ} \mathrm{C}$ were around 0.43 (0.395 to 0.460 for different size particles) and 0.64 (0.595 to 0.655$)$, which are comparable to the calculated VFR ( 0.467 for the $0.5: 0.5$ samples and 0.645 for the $0.75: 0.25$ samples). These results indicate that the role of HULIS-AS interactions in the volatility of their mixtures is complex and nonlinear.

In order to quantify the volatility changes of water-soluble HULIS induced by its interaction with ammonium sulfate, the kinetic mass transfer model was again applied to estimate the mass fractions of SVOC, LVOC and ELVOC for the HULIS part in the mixed samples. As shown in Fig. 7, the model's performance in simulating mixed HULIS-AS samples was fairly good, yet poorer than in simulating the "pure" HULIS sample. The poorest agreement between the simulated and measured evaporation curves was found for the $1: 3$ mixed samples (mass ratio of HULIS to AS), indicating relatively high uncertainties in the calculated mass fractions of compounds with different volatility bins for this mixture. These visible differences between modeled and measured results indicate that interactions between water-soluble HULIS and AS indeed influence their volatility distribution. As can be seen from Fig. 8, the estimated fraction of ELVOC in the HULIS part of the 0:25:0.75 (Fig. 8b) and $0.75: 0.25$ (Fig. 8d) samples was much higher than in the pure HULIS sample (Fig. 8a), while the ELVOC fraction in the $0.5: 0.5$ sample was comparable to that in the pure HULIS sample. By taking 30 and $145 \mathrm{~nm}$ particles as an example, the corresponding estimated ELVOC fractions were 0.66 and 0.26 in the pure HULIS sample, 1.0 and 0.93 in the $0.25: 0.75 \mathrm{sam}$ - 

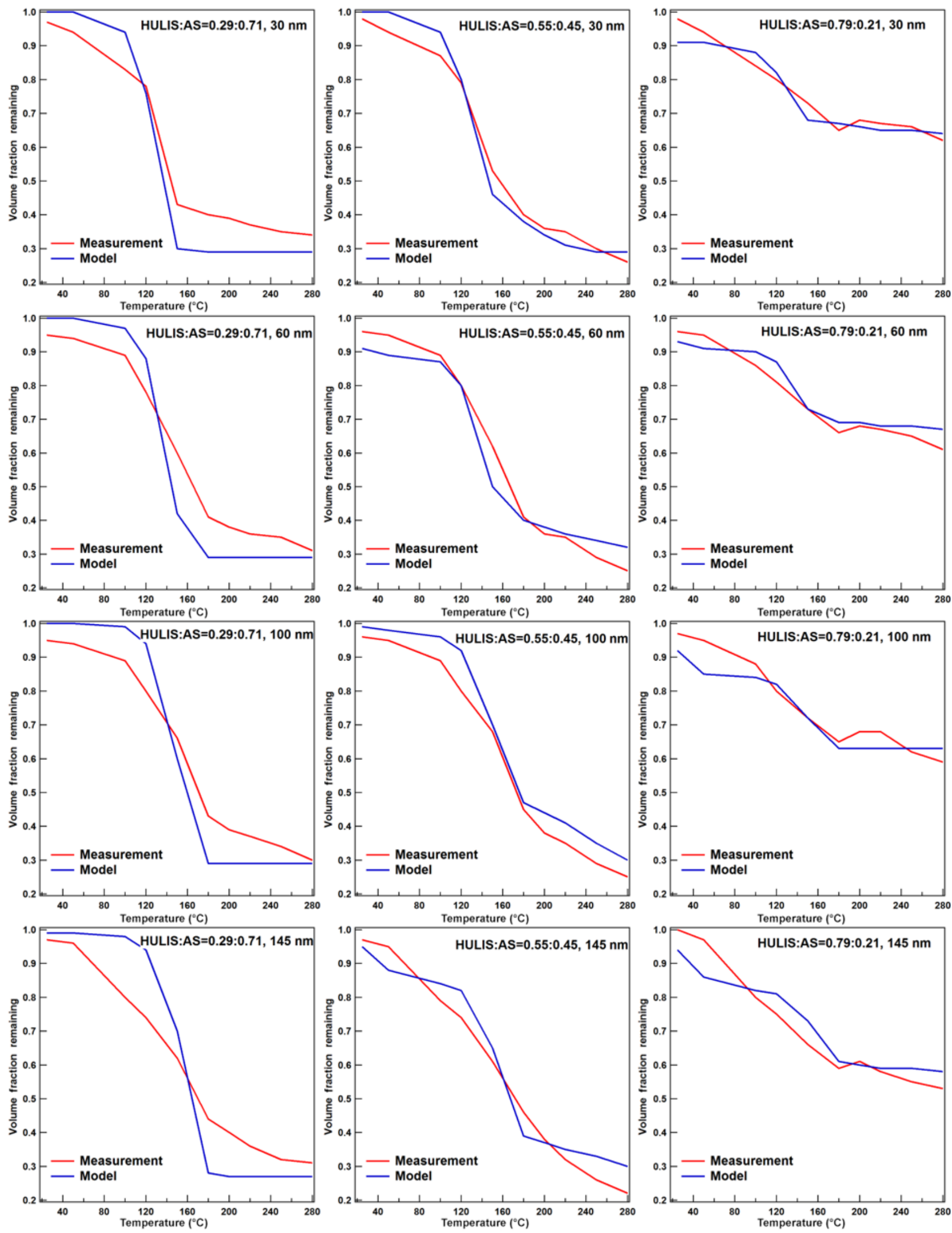

Figure 7. Measured and modeled volume fraction remaining (VFR) as a function of temperature for HULIS-AS mixed samples of three different mixing ratios at four different particle sizes of 30, 60, 100 and $145 \mathrm{~nm}$. 
(a) Pure HULIS of Sample 1

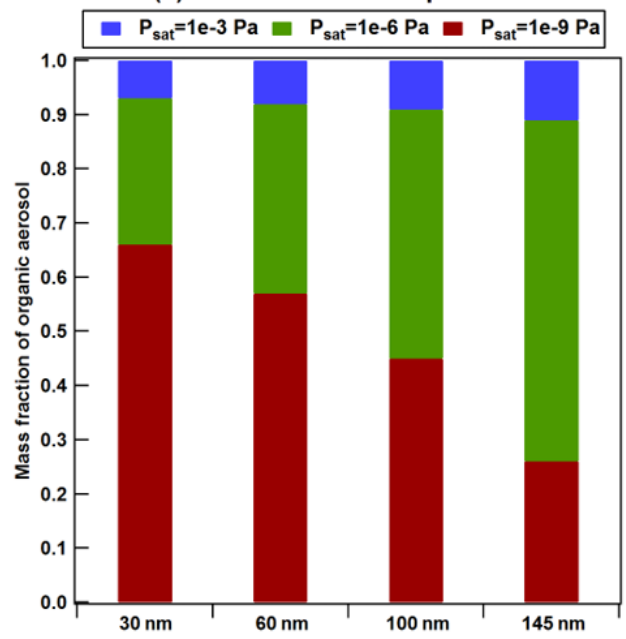

(c) HULIS:AS $=0.55: 0.45$

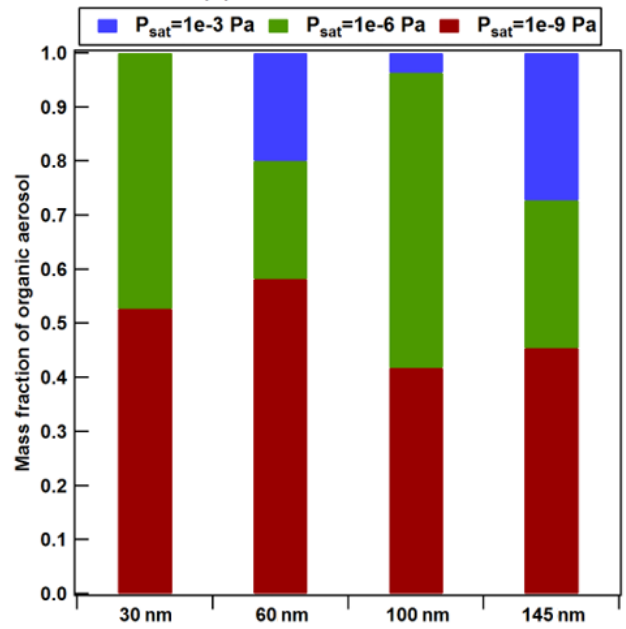

(b) HULIS:AS=0.29:0.71

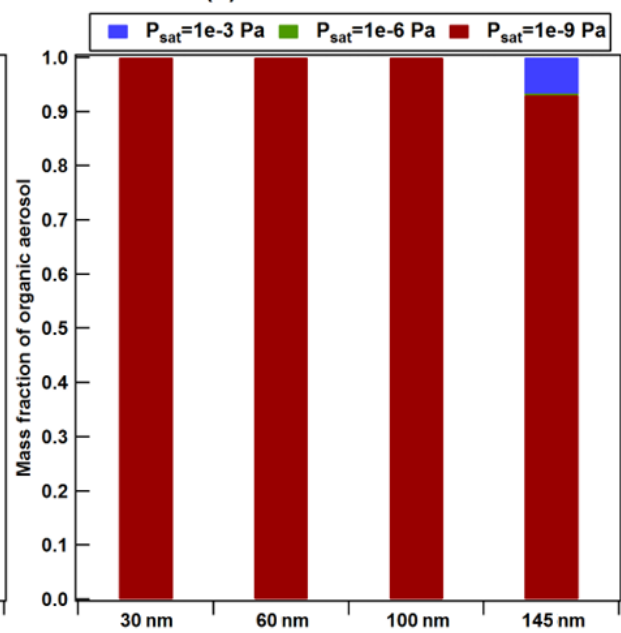

(d) HULIS:AS $=0.79: 0.21$

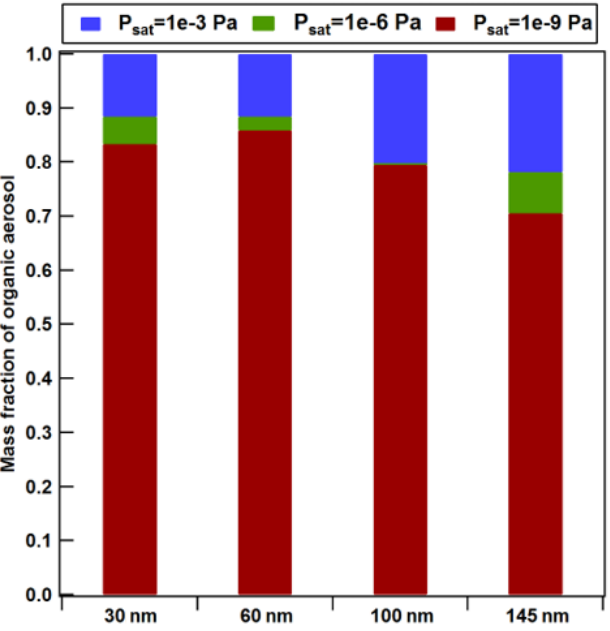

Figure 8. Model-derived mass fractions of organic compounds with different volatilities in four aerosol samples with different particle sizes of (a) $30 \mathrm{~nm}$, (b) $60 \mathrm{~nm}$, (c) $100 \mathrm{~nm}$, and (d) $145 \mathrm{~nm}$.

ple, 0.53 and 0.45 in the $0.5: 0.5$ sample, and 0.83 and 0.71 in the $0.75: 0.25$ sample, respectively. In spite of the possible overestimation of ELVOC fraction in $1: 3$ mixed samples, these results suggest that the interaction between watersoluble HULIS and ammonium sulfate tend to decrease the volatility of HULIS, and that this effect is nonlinear. It should be emphasized here in case HULIS are always mixed with ammonium sulfate, which accounted for $30 \%$ of the mass of $\mathrm{PM}_{2.5}$ (Xie et al., 2015), in ambient aerosols of YRD region, it is possible that these mixed samples are more representative of the real volatility of HULIS in ambient aerosols.

\section{Conclusion and implication}

In this study, we analyzed the volatility of atmospheric watersoluble HULIS extracted from four $\mathrm{PM}_{2.5}$ samples collected at the SORPES station in the western YRD of eastern China, and investigated how the interactions between water-soluble
HULIS and ammonium sulfate affected the volatility of HULIS aerosol fraction. Overall, low volatilities and highoxidation states were identified for all the four samples, with VFRs at $280^{\circ} \mathrm{C}$ being higher than $55 \%$ and $\mathrm{O}$ to $\mathrm{C}$ ratio being higher than 0.95 for all the regenerated HULIS particles. A kinetic mass transfer model was deployed to divide the HULIS mixture into SVOC, LVOC and ELVOC groups. We found that water-soluble HULIS were dominated by LVOC and ELVOC (more than $80 \%$ ) compounds. Given the possible thermo-decomposition of large molecules during the heating program, an even lower volatility than found here is possible for atmospheric HULIS in eastern China. The Kelvin effect was supposedly taking place in atomizing the solutions of the HULIS mixtures, which resulted in a size-dependent distribution of the relative fractions of SVOC, LVOC and ELVOC in the generated particles. The interaction between water-soluble HULIS and ammonium sulfate was found to decrease the volatility of the HULIS part in 
the mixed samples. However, these volatility changes were not linearly correlated with the mass fractions of ammonium sulfate, indicating a complex interaction between the HULIS mixture and inorganic salts.

This study demonstrates that HULIS are important lowvolatility and extremely low-volatility compounds in the aerosol phase, and sheds new light on the connection between atmospheric HULIS and ELVOC. In view of the important sources of HULIS, multiphase processes, including multiphase oxidation, oligomerization, polymerization and interaction with inorganic salts, have the potential to lower the volatility of organic compounds in the aerosol phase, and to influence their gas-aerosol partitioning. Multiphase processes could be one of the important reasons that most models tend to underestimate the formation of SOA.

Data availability. The data can be accessed upon contact with the corresponding authors.

\section{The Supplement related to this article is available online at doi:10.5194/acp-17-3659-2017-supplement.}

Competing interests. The authors declare that they have no conflict of interest.

Acknowledgements. This work was funded by the National Natural Science Foundation of China (D0512/41675145 and D0510/41505109), the National Key Research Program (2016YFC0202002 and 2016YFC0200506), and the Jiangsu Province Science Fund (BK20140021).

Edited by: J. Surratt

Reviewed by: four anonymous referees

\section{References}

Bilde, M., Barsanti, K., Booth, M., Cappa, C. D., Donahue, N. M., Emanuelsson, E. U., McFiggans, G., Krieger, U. K., Marcolli, C., Topping, D., Ziemann, P., Barley, M., Clegg, S., Dennis-Smither, B., Hallquist, M., Hallquist, Å. M., Khlystov, A., Kulmala, M., Mogensen, D., Percival, C. J., Pope, F., Reid, J. P., Ribeiro da Silva, M. A. V., Rosenoern, T., Salo, K., Soonsin, V. P., Yli-Juuti, T., Prisle, N. L., Pagels, J., Rarey, J., Zardini, A. A., and Riipinen, I.: Saturation Vapor Pressures and Transition Enthalpies of Low-Volatility Organic Molecules of Atmospheric Relevance: From Dicarboxylic Acids to Complex Mixtures, Chem. Rev., 115, 4115-4156, doi:10.1021/cr5005502, 2015.

Birdsall, A. W., Zentner, C. A., and Elrod, M. J.: Study of the kinetics and equilibria of the oligomerization reactions of 2-methylglyceric acid, Atmos. Chem. Phys., 13, 3097-3109, doi:10.5194/acp-13-3097-2013, 2013.

Canagaratna, M. R., Jayne, J. T., Jimenez, J. L., Allan, J. D., Alfarra, M. R., Zhang, Q., Onasch, T. B., Drewnick, F., Coe, H.,
Middlebrook, A., Delia, A., Williams, L. R., Trimborn, A. M., Northway, M. J., DeCarlo, P. F., Kolb, C. E., Davidovits, P., and Worsnop, D. R.: Chemical and microphysical characterization of ambient aerosols with the aerodyne aerosol mass spectrometer, Mass Spectrom. Rev., 26, 185-222, doi:10.1002/mas.20115, 2007.

Canagaratna, M. R., Jimenez, J. L., Kroll, J. H., Chen, Q., Kessler, S. H., Massoli, P., Hildebrandt Ruiz, L., Fortner, E., Williams, L. R., Wilson, K. R., Surratt, J. D., Donahue, N. M., Jayne, J. T., and Worsnop, D. R.: Elemental ratio measurements of organic compounds using aerosol mass spectrometry: characterization, improved calibration, and implications, Atmos. Chem. Phys., 15, 253-272, doi:10.5194/acp-15-253-2015, 2015.

Chen, Q., Ikemori, F., Higo, H., Asakawa, D., and Mochida, M.: Chemical Structural Characteristics of HULIS and Other Fractionated Organic Matter in Urban Aerosols: Results from Mass Spectral and FT-IR Analysis, Environ. Sci. Technol., 50, 17211730, doi:10.1021/acs.est.5b05277, 2016.

DeCarlo, P. F., Kimmel, J. R., Trimborn, A., Northway, M. J., Jayne, J. T., Aiken, A. C., Gonin, M., Fuhrer, K., Horvath, T., Docherty, K. S., Worsnop, D. R., and Jimenez, J. L.: Field-Deployable, High-Resolution, Time-of-Flight Aerosol Mass Spectrometer, Anal. Chem., 78, 8281-8289, doi:10.1021/ac061249n, 2006.

Dinar, E., Mentel, T. F., and Rudich, Y.: The density of humic acids and humic like substances (HULIS) from fresh and aged wood burning and pollution aerosol particles, Atmos. Chem. Phys., 6, 5213-5224, doi:10.5194/acp-6-5213-2006, 2006.

Ding, A. J., Fu, C. B., Yang, X. Q., Sun, J. N., Zheng, L. F., Xie, Y. N., Herrmann, E., Nie, W., Petäjä, T., Kerminen, V.-M., and Kulmala, M.: Ozone and fine particle in the western Yangtze River Delta: an overview of $1 \mathrm{yr}$ data at the SORPES station, Atmos. Chem. Phys., 13, 5813-5830, doi:10.5194/acp-13-58132013, 2013.

Ding, A. J., Nie, W., Huang, X., Chi, X., Sun, J., Kerminen, V. M., Xu, Z., Guo, W., Petaja, T., Yang, X. Q., Kulmala, M., and Fu, C.: Long-term observation of air pollution-weather/climate interactions at the SORPES station: A review and outlook, Front. Environ. Sci. Eng., 10, doi:10.1007/s11783-016-0877-3, online first, 2016.

Donahue, N. M., Hartz, K. E. H., Chuong, B., Presto, A. A., Stanier, C. O., Rosenhørn, T., Robinson, A. L., and Pandis, S. N.: Critical factors determining the variation in SOA yields from terpene ozonolysis: A combined experimental and computational study, Faraday Discuss., 130, 295-309, 2005.

Donahue, N. M., Kroll, J. H., Pandis, S. N., and Robinson, A. L.: A two-dimensional volatility basis set - Part 2: Diagnostics of organic-aerosol evolution, Atmos. Chem. Phys., 12, 615-634, doi:10.5194/acp-12-615-2012, 2012.

Ehn, M., Thornton, J. A., Kleist, E., Sipila, M., Junninen, H., Pullinen, I., Springer, M., Rubach, F., Tillmann, R., Lee, B., LopezHilfiker, F., Andres, S., Acir, I.-H., Rissanen, M., Jokinen, T., Schobesberger, S., Kangasluoma, J., Kontkanen, J., Nieminen, T., Kurten, T., Nielsen, L. B., Jorgensen, S., Kjaergaard, H. G., Canagaratna, M., Maso, M. D., Berndt, T., Petaja, T., Wahner, A., Kerminen, V.-M., Kulmala, M., Worsnop, D. R., Wildt, J., and Mentel, T. F.: A large source of low-volatility secondary organic aerosol, Nature, 506, 476-479, doi:10.1038/nature13032, 2014. 
Graber, E. R. and Rudich, Y.: Atmospheric HULIS: How humic-like are they? A comprehensive and critical review, Atmos. Chem. Phys., 6, 729-753, doi:10.5194/acp-6-729-2006, 2006.

Häkkinen, S. A. K., McNeill, V. F., and Riipinen, I.: Effect of Inorganic Salts on the Volatility of Organic Acids, Environ. Sci. Technol., 48, 13718-13726, doi:10.1021/es5033103, 2014.

Hoffer, A., Gelencsér, A., Guyon, P., Kiss, G., Schmid, O., Frank, G. P., Artaxo, P., and Andreae, M. O.: Optical properties of humic-like substances (HULIS) in biomass-burning aerosols, Atmos. Chem. Phys., 6, 3563-3570, doi:10.5194/acp-6-3563-2006, 2006.

Hong, J., Häkkinen, S. A. K., Paramonov, M., Äijälä, M., Hakala, J., Nieminen, T., Mikkilä, J., Prisle, N. L., Kulmala, M., Riipinen, I., Bilde, M., Kerminen, V.-M., and Petäjä, T.: Hygroscopicity, $\mathrm{CCN}$ and volatility properties of submicron atmospheric aerosol in a boreal forest environment during the summer of 2010, Atmos. Chem. Phys., 14, 4733-4748, doi:10.5194/acp-144733-2014, 2014.

Jimenez, J. L., Canagaratna, M. R., Donahue, N. M., Prevot, A. S. H., Zhang, Q., Kroll, J. H., DeCarlo, P. F., Allan, J. D., Coe, H., Ng, N. L., Aiken, A. C., Docherty, K. S., Ulbrich, I. M., Grieshop, A. P., Robinson, A. L., Duplissy, J., Smith, J. D., Wilson, K. R., Lanz, V. A., Hueglin, C., Sun, Y. L., Tian, J., Laaksonen, A., Raatikainen, T., Rautiainen, J., Vaattovaara, P., Ehn, M., Kulmala, M., Tomlinson, J. M., Collins, D. R., Cubison, M. J., E., Dunlea, J., Huffman, J. A., Onasch, T. B., Alfarra, M. R., Williams, P. I., Bower, K., Kondo, Y., Schneider, J., Drewnick, F., Borrmann, S., Weimer, S., Demerjian, K., Salcedo, D., Cottrell, L., Griffin, R., Takami, A., Miyoshi, T., Hatakeyama, S., Shimono, A., Sun, J. Y., Zhang, Y. M., Dzepina, K., Kimmel, J. R., Sueper, D., Jayne, J. T., Herndon, S. C., Trimborn, A. M., Williams, L. R., Wood, E. C., Middlebrook, A. M., Kolb, C. E., Baltensperger, U., and Worsnop, D. R.: Evolution of Organic Aerosols in the Atmosphere, Science, 326, 1525-1529, doi:10.1126/science.1180353, 2009.

Kanakidou, M., Seinfeld, J. H., Pandis, S. N., Barnes, I., Dentener, F. J., Facchini, M. C., Van Dingenen, R., Ervens, B., Nenes, A., Nielsen, C. J., Swietlicki, E., Putaud, J. P., Balkanski, Y., Fuzzi, S., Horth, J., Moortgat, G. K., Winterhalter, R., Myhre, C. E. L., Tsigaridis, K., Vignati, E., Stephanou, E. G., and Wilson, J.: Organic aerosol and global climate modelling: a review, Atmos. Chem. Phys., 5, 1053-1123, doi:10.5194/acp-5-1053-2005, 2005

Kiss, G., Tombácz, E., Varga, B., Alsberg, T., and Persson, L.: Estimation of the average molecular weight of humic-like substances isolated from fine atmospheric aerosol, Atmos. Environ., 37, 3783-3794, doi:10.1016/S1352-2310(03)00468-0, 2003.

Kiss, G., Tombácz, E., and Hansson, H.-C.: Surface Tension Effects of Humic-Like Substances in the Aqueous Extract of Tropospheric Fine Aerosol, J. Atmos. Chem., 50, 279-294, doi:10.1007/s10874-005-5079-5, 2005.

Kristensen, T. B., Wex, H., Nekat, B., Nøjgaard, J. K., van Pinxteren, D., Lowenthal, D. H., Mazzoleni, L. R., Dieckmann, K., Bender Koch, C., Mentel, T. F., Herrmann, H., Gannet Hallar, A., Stratmann, F., and Bilde, M.: Hygroscopic growth and CCN activity of HULIS from different environments, J. Geophys. Res.Atmos., 117, D22203, doi:10.1029/2012JD018249, 2012.

Kristensen, T. B., Prisle, N. L., and Bilde, M.: Cloud droplet activation of mixed model HULIS and $\mathrm{NaCl}$ particles: Experi- mental results and $\kappa$-Köhler theory, Atmos. Res., 137, 167-175, doi:10.1016/j.atmosres.2013.09.017, 2014.

Kristensen, T. B., Du, L., Nguyen, Q. T., Nøjgaard, J. K., Koch, C. B., Nielsen, O. F., Hallar, A. G., Lowenthal, D. H., Nekat, B., Pinxteren, D. v., Herrmann, H., Glasius, M., Kjaergaard, H. G., and Bilde, M.: Chemical properties of HULIS from three different environments, J. Atmos. Chem., 72, 65-80, doi:10.1007/s10874-015-9302-8, 2015.

Krivácsy, Z., Kiss, G., Ceburnis, D., Jennings, G., Maenhaut, W., Salma, I., and Shooter, D.: Study of water-soluble atmospheric humic matter in urban and marine environments, Atmos. Res. 87, 1-12, doi:10.1016/j.atmosres.2007.04.005, 2008.

Kroll, J. H. and Seinfeld, J. H.: Chemistry of secondary organic aerosol: Formation and evolution of low-volatility organics in the atmosphere, Atmos. Environ., 42, 3593-3624, doi:10.1016/j.atmosenv.2008.01.003, 2008.

Laskin, A., Moffet, R. C., Gilles, M. K., Fast, J. D., Zaveri, R. A., Wang, B., Nigge, P., and Shutthanandan, J.: Tropospheric chemistry of internally mixed sea salt and organic particles: Surprising reactivity of $\mathrm{NaCl}$ with weak organic acids, J. Geophys. Res.Atmos., 117, D15302, doi:10.1029/2012jd017743, 2012.

Li, Y., Pöschl, U., and Shiraiwa, M.: Molecular corridors and parameterizations of volatility in the chemical evolution of organic aerosols, Atmos. Chem. Phys., 16, 3327-3344, doi:10.5194/acp16-3327-2016, 2016.

Lin, P. and Yu, J. Z.: Generation of Reactive Oxygen Species Mediated by Humic-like Substances in Atmospheric Aerosols, Environ. Sci. Technol., 45, 10362-10368, doi:10.1021/es2028229, 2011.

Lin, P., Engling, G., and Yu, J. Z.: Humic-like substances in fresh emissions of rice straw burning and in ambient aerosols in the Pearl River Delta Region, China, Atmos. Chem. Phys., 10, 64876500, doi:10.5194/acp-10-6487-2010, 2010a.

Lin, P., Huang, X.-F., He, L.-Y., and Zhen Yu, J.: Abundance and size distribution of HULIS in ambient aerosols at a rural site in South China, J. Aerosol Sci., 41, 74-87, doi:10.1016/j.jaerosci.2009.09.001, 2010b.

Lin, P., Rincon, A. G., Kalberer, M., and Yu, J. Z.: Elemental Composition of HULIS in the Pearl River Delta Region, China: Results Inferred from Positive and Negative Electrospray High Resolution Mass Spectrometric Data, Environ. Sci. Technol., 46, 7454-7462, doi:10.1021/es300285d, 2012.

Lukács, H., Gelencsér, A., Hammer, S., Puxbaum, H., Pio, C., Legrand, M., Kasper-Giebl, A., Handler, M., Limbeck, A., Simpson, D., and Preunkert, S.: Seasonal trends and possible sources of brown carbon based on 2-year aerosol measurements at six sites in Europe, J. Geophys. Res.-Atmos., 112, D23S18, doi:10.1029/2006JD008151, 2007.

Ma, Q., Ma, J., Liu, C., Lai, C., and He, H.: Laboratory Study on the Hygroscopic Behavior of External and Internal C2-C4 Dicarboxylic Acid-NaCl Mixtures, Environ. Sci. Technol., 47, 1038110388, doi:10.1021/es4023267, 2013.

Molteni, U., Bianchi, F., Klein, F., El Haddad, I., Frege, C., Rossi, M. J., Dommen, J., and Baltensperger, U.: Formation of highly oxygenated organic molecules from aromatic compounds, Atmos. Chem. Phys. Discuss., doi:10.5194/acp-2016-1126, in review, 2016.

Murphy, B. N., Donahue, N. M., Robinson, A. L., and Pandis, S. N.: A naming convention for atmospheric organic aerosol, At- 
mos. Chem. Phys., 14, 5825-5839, doi:10.5194/acp-14-58252014, 2014.

Offenberg, J. H., Kleindienst, T. E., Jaoui, M., Lewandowski, M., and Edney, E. O.: Thermal properties of secondary organic aerosols, Geophys. Res. Lett., 33, L03816, doi:10.1029/2005GL024623, 2006.

Ortiz-Montalvo, D. L., Häkkinen, S. A. K., Schwier, A. N., Lim, Y. B., McNeill, V. F., and Turpin, B. J.: Ammonium addition (and aerosol $\mathrm{pH}$ ) has a dramatic impact on the volatility and yield of glyoxal secondary organic aerosol, Environ. Sci. Technol., 48, 255-262, doi:10.1021/es4035667, 2014.

Paciga, A. L., Riipinen, I., and Pandis, S. N.: Effect of ammonia on the volatility of organic diacids, Environ. Sci. Technol., 48, 13769-13775, doi:10.1021/es5037805, 2014.

Paglione, M., Kiendler-Scharr, A., Mensah, A. A., Finessi, E., Giulianelli, L., Sandrini, S., Facchini, M. C., Fuzzi, S., Schlag, P., Piazzalunga, A., Tagliavini, E., Henzing, J. S., and Decesari, S.: Identification of humic-like substances (HULIS) in oxygenated organic aerosols using NMR and AMS factor analyses and liquid chromatographic techniques, Atmos. Chem. Phys., 14, 2545, doi:10.5194/acp-14-25-2014, 2014.

Riipinen, I., Pierce, J. R., Donahue, N. M., and Pandis, S. N.: Equilibration time scales of organic aerosol inside thermodenuders: Evaporation kinetics versus thermodynamics, Atmos. Environ., 44, 597-607, doi:10.1016/j.atmosenv.2009.11.022, 2010.

Verma, V., Rico-Martinez, R., Kotra, N., King, L., Liu, J., Snell, T. W., and Weber, R. J.: Contribution of Water-Soluble and Insoluble Components and Their Hydrophobic/Hydrophilic Subfractions to the Reactive Oxygen Species-Generating Potential of Fine Ambient Aerosols, Environ. Sci. Technol., 46, 1138411392, doi:10.1021/es302484r, 2012.

Wex, H., Hennig, T., Salma, I., Ocskay, R., Kiselev, A., Henning, S., Massling, A., Wiedensohler, A., and Stratmann, F.: Hygroscopic growth and measured and modeled critical super-saturations of an atmospheric HULIS sample, Geophys. Res. Lett., 34, L02818, doi:10.1029/2006GL028260, 2007.
Winklmayr, W., Reischl, G. P., Lindner, A. O., and Berner, A.: A new electromobility spectrometer for the measurement of aerosol size distributions in the size range from 1 to $1000 \mathrm{~nm}$, J. Aerosol Sci., 22, 289-296, doi:10.1016/S0021-8502(05)80007-2, 1991.

Xie, Y., Ding, A., Nie, W., Mao, H., Qi, X., Huang, X., Xu, Z., Kerminen, V.-M., Petäjä, T., Chi, X., Virkkula, A., Boy, M., Xue, L., Guo, J., Sun, J., Yang, X., Kulmala, M., and Fu, C.: Enhanced sulfate formation by nitrogen dioxide: Implications from in situ observations at the SORPES station, J. Geophys. Res.-Atmos., 120, 12679-12694, doi:10.1002/2015JD023607, 2015.

Yli-Juuti, T., Zardini, A. A., Eriksson, A. C., Hansen, A. M., Pagels, J. H., Swietlicki, E., Svenningsson, B., Glasius, M., Worsnop, D. R., Riipinen, I., and Bilde, M.: Volatility of organic aerosol: Evaporation of ammonium sulfate/succinic acid aqueous solution droplets, Environ. Sci. Technol., 47, 12123-12130, doi:10.1021/es401233c, 2013.

Zardini, A. A., Riipinen, I., Koponen, I. K., Kulmala, M., and Bilde, M.: Evaporation of ternary inorganic/organic aqueous droplets: Sodium chloride, succinic acid and water, J. Aerosol Sci., 41, 760-770, doi:10.1016/j.jaerosci.2010.05.003, 2010.

Zhang, Q., Jimenez, J. L., Canagaratna, M. R., Allan, J. D., Coe, H., Ulbrich, I., Alfarra, M. R., Takami, A., Middlebrook, A. M., Sun, Y. L., Dzepina, K., Dunlea, E., Docherty, K., DeCarlo, P. F., Salcedo, D., Onasch, T., Jayne, J. T., Miyoshi, T., Shimono, A., Hatakeyama, S., Takegawa, N., Kondo, Y., Schneider, J., Drewnick, F., Borrmann, S., Weimer, S., Demerjian, K., Williams, P., Bower, K., Bahreini, R., Cottrell, L., Griffin, R. J., Rautiainen, J., Sun, J. Y., Zhang, Y. M., and Worsnop, D. R.: Ubiquity and dominance of oxygenated species in organic aerosols in anthropogenically-influenced Northern Hemisphere midlatitudes, Geophys. Res. Lett., 34, L13801, doi:10.1029/2007GL029979, 2007. 